\section{The Tercentenary of Cinchona in Medicine.}

\begin{abstract}
$\mathrm{A}^{\mathrm{S}}$ a nation we are much less inclined than some of our Continental neighbours to celebrate historical events. It is therefore somewhat surprising to find that the tercentenary of the introduction of cinchona bark into European medicine (see NATURE, Nov. 29, p. 850) is being commemorated in London. Dr. H. S. Wellcome, whose interest in everything that pertains to the history or the progress of medicine is well known, has arranged at the Wellcome Historical Medical Museum, 54 Wigmore Street, London, W.I, an extremely interesting exhibition of materials, manuscripts, and literature relating to this drug. The Museum itself is rich in specimens of cinchona bark of historic interest, and possesses many rare documents and books on the subject, as well as pictures of personalities who have achieved fame as explorers of the Peruvian cinchona forests, of whom Dr. Wellcome is himself an example. To this nucleus has been added for this occasion gifts and loans from governments, learned societies, and institutions in various parts of the world, with the result that never before has such a collection of material for the study of cinchona been gathered together. The exhibition will continue open for several weeks.
\end{abstract}

Among the items of general interest may be mentioned three of the original packages of cinchona bark brought from Peru by Ruiz and Pavon on their return from the expedition sent there by Carlos III. in 1777. These are shown by H.M. the King of Spain. The Secretary of State for India has contributed five blue-books and the volume of original correspondence in manuscript (1859-70) relating to Sir Clements Markham's expedition to Peru in connexion with the introduction of cinchona into India. No less interesting are some of the Museum's own treasures : for example, the original specimens of quinine and cinchonine isolated by Pelletier and Caventou in 1827, autograph letters of La Condamine and De Vrij, and the original 'permit' issued by the Peruvian Minister of Foreign Affairs to Sir Clements Markham to enable him to carry out work in the cinchona forests. For the more technical visitor there are the extensive collections of botanical material lent by the Royal Botanical Gardens, Kew; Messrs. Howard and Sons, Ltd.; the Imperial Institute, and the Pharmaceutical Society of London. Not least important is the malaria section of the Wellcome Medical Museum at Endsleigh Court, which has been transferred en bloc to the exhibition. The task of the visitor has been made easy by the excellent arrangement of the exhibits, the clear numbering of the specimens, and the beautifully produced catalogue.

Not content with having produced this tribute to the pioneers who discovered and brought cinchona into medical use, Dr. Wellcome arranged a series of receptions at which addresses were given by authorities on the history and uses of the drug. At the first of these, on Monday, Dec. 8, which also served as an opening ceremony, the chair was appropriately taken by Cardinal Bourne and addresses were delivered by the Ambassadors for Spain and France, whilst the Minister for Peru gave a short but interesting critical survey of the usually accepted history of cinchona. At the evening reception on the same day diplomacy and the Roman Catholic Church were still predominant, the chair being taken by the Ambassador for Holland, whilst the address was given by Cardinal Bourne's able coadjutor, Archbishop Goodier, who continued and extended the criticism of the history of cinchona as usually written. Both critics combined to demolish part of the romantic story which has been woven around the name of the Countess of Chinchon, and both declined to accept von Humboldt's statement that the natives of Peru were unaware of the virtues of cinchona.

At the receptions on Wednesday, Dec. 10, the addresses on the more technical aspects of cinchona began. 'In the afternoon Dr. Wellcome took the chair, whilst Sir David Prain gave the distinguished audience the fruits of his unique experience with cinchona, both as a botanist and in the capacity of a former Director of the Indian Government Cinchona Plantations, as a planter, and a quinine manufacturer. It was particularly interesting to hear this eminent authority account for the abandonment of cinchona planting in Ceylon, not by lack of enterprise or skill on the part of the British planters, but by unalterable natural causes, the chief being unsuitable soil. Sir David is also of opinion that it is unwise to devote so much attention to quinine, to the exclusion of the other cinchona alkaloids. This point was also emphasised by Prof. H. E. Armstrong, who paid a tribute to Dr. Wellcome's long-continued and generous support of chemical research, and hoped that part of the energies of the various Wellcome research institutions would shortly be devoted to solving some of the many problems which the proper and economical use of cinchona still presents for solution by chemists, pharmacologists, and clinicians.

At the evening reception the principal address was given by Sir Humphry Rolleston, who provided many interesting medical sidelights on the history of cinchona and finished with an admirable summary of the therapeutics of the drug. During the present week further receptions are being given, at which the speakers will include General Sir Charles MacWatt, formerly Director-General of the Indian Medical Service; Dr. Manson-Bahr, Dr. H. H. Dale, Dr. C. M. Wenyon, and others.

\section{University and Educational Intelligence.}

BIRMINGHAM. - The increase in number of students in the Department of Oil Engineering has necessitated the erection of additional buildings adjoining the existing Oil Block. The new buildings, which are nearly complete, include a laboratory for ordinary students, a 'large-scale' laboratory, and stores. An extension of space for research will thus become available and the congested conditions under which research work is at present being carried on will be relieved. The Department of Civil Engineering has also been extended by the erection of a large Cement Laboratory.

The Council of the University has agreed to make a contribution to the funds of the Port Erin Biological Station.

London.-Applications are invited for two Keddey Fletcher-Warr studentships for the promotion of postgraduate research. Each studentship will be of the annual value of not less than $£ 250$ and tenable for three years. Application forms and further particulars may be had from the Academic Registrar, University of London, South Kensington, S.W.7, to whom completed forms must be returned by Feb. 20 .

A vacAtion course in photogrammetry is announced to take place in the Technical-Physical Institute of the University of Jena on Mar. 16-28 next, when lectures will be given on the elements of photogrammetry, the historical development of photogrammetry, terrestrial photogrammetry, and aerophotogrammetry. Applications for the course will be received until Mar. 1 by Mr. A. Kramer, Schützenstrasse 72, Jena, Germany.

No. 3190, VoL. 126] 
Applications are invited for the Theresa Seessel research fellowship of Yale University, the object of which is the promotion of original research in biological studies, and the value about $£ 300$. The holder of the fellowship must reside in New Haven during the college year, October to June. Applications should be made to the Dean of the Graduate School, New Haven, Connecticut, U.S.A., before Mar. 1.

THE thirty-first annual meeting of the Science Masters' Association will be held at Birmingham, in the University buildings, on Jan. 6-9, under the presidency of Sir Charles Grant Robertson, who will deliver his presidential address on the evening of the first day of the meeting. The programme includes lectures on the lunar landscape (Mr. J. Young), complex molecular structures (Prof. W. N. Haworth), the physicist and chemist in the petroleum industry (Prof. A. W. Nash), science education of boys up to eighteen years of age (Prof. F. W. Burstall), and zoological experiments for school work (Prof. $H$. Munro Fox), while the Bishop of Birmingham is to give a lecture entitled "A Finite Universe ?" Mr. F. Fairbrother will open a discussion on general science, and a meeting will be held with representatives of the Commission on Educational and Cultural Films. Demonstrations will be given in the University departments of science and technology, and visits to industrial works in the locality are being arranged. There will also be a trade exhibition of books and apparatus during the meeting.

\section{Historic Natural Events.}

Dec. 2I, I58I. Drought.-1581 was described as the droughtiest year that any man had known. On Dec. 21 the river Trent dried up at Alrewas, Staffordshire, on account of the lack of rain.

Dec. 22, 987. Beginning of Long Frost in Western Europe.-On this date a frost began which was said to have lasted 120 days in England. In France the autumn sowings were destroyed by the cold of winter and the drought of spring.

Dec. 22, r664. Severe Winter and Comet.-Under this date John Evelyn records that "this year I planted the lower grove next the pond at Sayes Court. It was now exceeding cold, and a hard long frosty season, and the Comet was very visible."

Dec. 22, I894. Gale over England.-A violent westerly gale of short duration prevailed over the whole of England, Ireland, and southern Scotland during the morning, the average velocity at Fleet wood from 8.30 to 9.30 A.M. being 79 miles per hour. The storm caused much damage on land and loss of life at sea, and sea salt was carried inland as far as Birmingham (55 miles) and Masham in Yorkshire (65 miles inland).

Dec. 25, 1739. Severe Winter in England.-The winter of $1739-40$ was very rigorous, though somewhat less so than $1607-8$ or 1708-9. After a cold spell on Nov. 24-30, there was a warmer interval in December, but the frost commenced on Christmas Day and continued until Feb. 17. There was a second period of cold on Feb. 23-26. At the beginning of January a high wind caused great damage to the shipping in the Thames, several ships laden with corn and coal being sunk by the sheets of drifting ice; many lives were lost. Above London Bridge the Thames was completely frozen over and a 'frost fair' was held, with sports, shops, and a printing press. An ox was roasted whole on the ice, in imitation of the ceremony in 1640 . A printing press was also set up on the Ouse at York. The frost was very severe on the Continent; the Zuider Zee was completely frozen, and also the sea off Ostend. A curiosity was the palace built entirely of ice on the banks of the Neva, with six cannon made entirely of ice, one of which was actually fired without being injured. The wind over western Europe was north-easterly throughout, and there was little snow.

Dec. 25, 1923. Hail. - Intense thunderstorms occurred over the Transvaal at Pretoria and to the south-eastward. Two storms struck Pretoria, the first at 6.25 P.M. and the second at 7.30 P.M. The first storm was accompanied by hailstones, some of which weighed more than five ounces. Tiled roofs were almost totally destroyed and even galvanised iron roofs were pierced; the damage to property amounted to $£ 80,000$.

Dec. 25, 1927. Snowstorm in England.-The Christmas snowstorm of 1927 is described in British Rainfall as "one of the worst experienced in living memory". On Dec. 25 there was snow in the Midlands but continuous rain in the south of England. In the evening the rain changed to snow, which fell heavily over south-east England during the night and throughout Dec. 26 and the following night. It was accompanied by a strong north-easterly wind, which formed heavy drifts, some of them $20 \mathrm{ft}$. deep ; many main roads were completely blocked for days and some secondary roads for weeks. Motor-cars had to be abandoned, and some were completely buried in snow. Many villages were practically cut off from the world, and a few had to be provisioned by parcels dropped from aeroplanes. On Jan. 21, 1928, six or seven feet of snow still lay in some of the Hampshire roads. The storm was most severe and the snow deepest on Dartmoor, in the Alton-Basing. stoke district, and along the North Downs.

Dec. 26-30, 1906. Snowstorms in British Isles.Snow fell heavily over the greater part of the British Isles during these five days. The depth was greatest in the south of Scotland, where numerous trains were snowed up; Aberdeen was isolated for three days, and near Arbroath a railway collision cost many lives. In Ireland the snowfall was probably the greatest on record for depth and intensity. During the same week heavy snow fell also in eastern Europe, accompanied by a high wind which caused it to accumulate in deep drifts.

Dec. 27, I8I3. London Fog.-It is recorded in the Annals of Philosophy that between Dec. 27, 1813, and Jan. 2, 1814, " a most extraordinary fog prevailed in London, and seems to have extended a great many miles round in every direction. It was frequently so thick that it was impossible to see across the street; candles were burnt in most of the shops and counting. houses all day long. This fog condensed upon the grass, the trees, and every wooden or iron railings. The grass was covered with a coating of snow (condensed fog) at least half an inch thick. Below the trees in St. James's Park there lay a bed of snow an inch thick at least, which had fallen from them. In London the thickness of the fog was still further increased by the smoke of the city; so much so, that it produced a very sensible effect on the eyes, and the coal tar varnish might be distinctly perceived by the smell. But at a distance from town, though there was no smoke, the fog was very thick, not a breath of wind was perceptible during the whole week."

\section{Erratum.}

Dec. 9-I1, r672. Glazed Frost in Somerset.-The record of this phenomenon in the abridged edition of the Philosophical Transactions, vol. 2, p. 37, implies that the year was 1671, but Mr. C. E. Britton, of the Meteorological Office, New Ranges, Shoeburyness, from a study of the unabridged edition, states that the correct date should be $\mathbf{1 6 7 2}$. 